\title{
A New Subspecies Identification and Population Study of the Asian Small-Clawed Otter (Aonyx cinereus) in Malay Peninsula and Southern Thailand Based on Fecal DNA Method
}

\author{
M. K. A. Rosli, ${ }^{1}$ S. M. F. Syed-Shabthar, ${ }^{1}$ P. Abdul-Patah, ${ }^{2}$ Z. Abdul-Samad, ${ }^{1}$ \\ S. N. Abdul, ${ }^{1}$ M. N. Burhanuddin, ${ }^{2}$ N. A. Zulkifli, ${ }^{1}$ M. N. Shukor, ${ }^{1}$ K. Budsabong, ${ }^{3}$ \\ S. Changtragoon, ${ }^{3}$ T. Sekiguchi, ${ }^{4}$ H. Sasaki, ${ }^{5}$ and B. M. Md-Zain ${ }^{1}$ \\ ${ }^{1}$ School of Environmental and Natural Resource Sciences, Faculty of Science and Technology, Universiti Kebangsaan Malaysia, \\ 43600 Bangi, Selangor, Malaysia \\ ${ }^{2}$ Department of Wildlife and National Parks, Km 10, Jalan Cheras, 50664 Kuala Lumpur, Malaysia \\ ${ }^{3}$ Department of National Park, Wildlife and Plant Conservation Office, Ladyao, Chatuchak, Bangkok 10900, Thailand \\ ${ }^{4}$ Department of Molecular Biology, Graduate School of Medical Science, Kyushu University, 3-1-1 Maidashi, Higashi-ku, \\ Fukuoka 812-8582, Japan \\ ${ }^{5}$ Chikushi Jogakuen University Junior College, 2-12-1 Ishizaka, Dazaifu 818-0192, Japan
}

Correspondence should be addressed to B. M. Md-Zain; abgbadd1966@yahoo.com

Received 10 October 2013; Accepted 29 December 2013; Published 13 March 2014

Academic Editors: A. Luchiari and E. Mushinzimana

Copyright (C) 2014 M. K. A. Rosli et al. This is an open access article distributed under the Creative Commons Attribution License, which permits unrestricted use, distribution, and reproduction in any medium, provided the original work is properly cited.

\begin{abstract}
Three species of otter can be found throughout Malay Peninsula: Aonyx cinereus, Lutra sumatrana, and Lutrogale perspicillata. In this study, we focused on the A. cinereus population that ranges from the southern and the east coast to the northern regions of Malay Peninsula up to southern Thailand to review the relationships between the populations based on the mitochondrial D-loop region. Forty-eight samples from six populations were recognized as Johor, Perak, Terengganu, Kelantan, Ranong, and Thale Noi. Among the 48 samples, 33 were identified as A. cinereus, seven as L. sumatrana, and eight as L. perspicillata. Phylogenetically, two subclades formed for A. cinereus. The first subclade grouped all Malay Peninsula samples except for samples from Kelantan, and the second subclade grouped Kelantan samples with Thai sample. Genetic distance analysis supported the close relationships between Thai and Kelantan samples compared to the samples from Terengganu and the other Malaysian states. A minimum-spanning network showed that Kelantan and Thailand formed a haplogroup distinct from the other populations. Our results show that Thai subspecies A. cinereus may have migrated to Kelantan from Thai mainland. We also suggest the classification of a new subspecies from Malay Peninsula, the small-clawed otter named $A$. cinereus kecilensis.
\end{abstract}

\section{Introduction}

Several methods for identifying species rely on DNA sequence analysis. Among them are RFLPs, AFLPs, RAPD, polymerase chain reaction, microarray, and DNA sequencing [1-4]. DNA-based methods are often used due to the reliability of DNA sequences, with the general assumption that individuals from the same species carry specific DNA (or protein) sequences that differ from those found in individuals from other species [5]. DNA is a strong tool in forensic analysis because DNA is extremely stable and lives long as a biological molecule that can be recovered from several types of forensic evidence such as bloodstains, feces, saliva, urine, and commercial products $[6,7]$.

DNA extraction from feces is among the most complicated and high-risk processes of noninvasive samples. After DNA has been extracted, problems are often encountered in terms of relatively low DNA yields and/or recovering DNA free of inhibitory substances [8]. These issues make fecal sampling less popular among geneticists. However, fecal samples are important in studies that require DNA sources from risky or highly endangered subjects before samples are 
collected in the wild $[4,9]$. With several nonconventional DNA extraction kits and enhanced PCR chemicals available today, DNA analysis of fecal sources is no longer impossible [10]. In this study, we focused on extracting DNA from fecal samples that are believed to be otter feces, collected from several regions, to identify species.

Otters belong to the mammalian order under the family Mustelidae and subfamily Lutrinae [11]. Thirteen otter species are found in the world, comprising seven distinct genera made up of three major clades based on nuclear and mitochondrial markers $[12,13]$. The three clades are the sea and river otters of Eurasia and Africa (Aonyx, Enhydra, Hydrictis, Lutra, and Lutrogale), the marine and river otters from North, Central, and South America (Lontra), and a basal lineage of Pteronura brasiliensis $[12,14,15]$.

In Malaysia, three species of Eurasian otter can be found throughout Malay Peninsula: Aonyx cinereus, Lutra sumatrana, and Lutrogale perspicillata $[11,16,17]$. The L. perspicillata and $A$. cinereus species are common in Malay Peninsula, where they are widely distributed, while L. sumatrana is rare but apparently still found in the eastern Malay Peninsula [18]. Based on previous systematic studies of morphological data, Lutra and Lutrogale are often grouped together in Lutrini clade, distinct from Amblonyx, which is grouped with Aonyx in Aonychini clade [19-21]. However, molecular data has indicated that L. perspicillata is a sister clade to A. cinereus in a higher clade distinct from L. sumatrana, a species previously closely related to L. perspicillata morphologically [14].

Among the three species, A. cinereus is the smallest, with an estimated average body size of less than $3.5 \mathrm{~kg}$ and measuring about 652-939 mm [11, 22, 23]. Morphologically, $A$. cinereus is characterized by a small head, a neck larger than the head, short legs, and a flat tail [21]. Their paws are very dexterous. The body color is light brown with greyish white color on the lips, chin, and sides of the neck [22]. Body size and smaller claws distinguish the $A$. cinereus from other otter species $[22,24]$.

Otters are adapted for a semiaquatic life and are bioindicators of wetland ecosystems [25]. A recent study showed that A. cinereus is considered "vulnerable" according to the IUCN Red List Criteria due to declining populations resulting from habitat loss and land exploitation [11]. A. cinereus has also been recognized as being "under local scrutiny" by the IUCN Otter Specialist Group for the Conservation of Nature [25]. Several studies reported the extent of the habitat losses occurring in South and Southeast Asia, and increased poaching has led to population reduction in many parts of the species' range [11, 26, 27]. In the wild, $A$. cinereus is probably the species most threatened by habitat destruction and pollution of the environment, especially due to chemical organochlorine [28]. These species are also killed for their skin, fur, and organs, which are believed to have medicinal value in Asia [28]. To date, studies investigating the population of $A$. cinereus are lacking, and nothing has been done specifically regarding the population reduction of this species.

Globally, A. cinereus is widely distributed from India throughout South Asia across Bangladesh, Myanmar, Thailand, Indonesia, and Malaysia and from Southeast Asia to the Philippines, Taiwan, and eastern and southern China in the north [11]. However, this small species is possibly extinct in Hong Kong and Singapore [28, 29]. A. cinereus inhabits coastal habitats and inland rivers, swamps, mangroves, and paddy fields up to $2000 \mathrm{~m}$ above sea level [30, 31]. This species often inhabits areas close to human activity [31]. A. cinereus coexists with L. sumatrana and L. perspicillata in many locations, including several rivers in Thailand and Malaysia [32]. Although all three species feed on the same prey, most A. cinereus members are crab eaters, while most of the other species feed on fish [33]. Coexistence is controlled by the selection of different habitats and food. In Southeast Asia, A. cinereus is abundant in irrigation canals and rice fields where L. sumatrana is not present [16]. On Malay Peninsula, A. cinereus is limited to small rivers and irrigation canals [34].

Geographic range and population studies are important to obtain information for requirements concerning ecology and conservation efforts to preserve species threatened with extinction [35]. In this phylogeography study, we focused on the $A$. cinereus population ranging from the southern and eastern coast to northern regions of Malay Peninsula up to southern Thailand to review the knowledge about the relationship between populations of this species using genetic methods. Species identified from fecal samples help us determine the species in sampling locations and the coexistence of multiple species. Our region of interest was the mitochondrial DNA, D-loop control region. The mitochondrial genome has been extensively used to amplify many genes of interest for phylogenetic studies [36-39]. Sequence divergence accumulates more rapidly in mitochondrial DNA (mtDNA) than in nuclear DNA due to the faster mutation rate and lack of repair system in mtDNA, which means that it often contains high levels of information variation [40]. The $\mathrm{D}$-loop is a highly variable noncoding control region that has the highest polymorphism rate among mitochondrial genes and is widely used in genetic population studies [9, 41-43].

\section{Materials and Methods}

2.1. Sampling Locations, Samples, and DNA Isolation. Genetic sampling involved several locations in Malay Peninsula including the northern region (Perak: Kuala Gula), the southern region (Johor: Sungai Pontian Besar, Parit Karang, and Sarang Buaya), and the eastern coastal region (Kelantan: Padang Salim, Tumpat; Terengganu: Penarik) of Malaysia and the southern region of Thailand (Ranong and Thale Noi) (Table 1). In this preliminary study, sampling locations were selected based on several reports of the existence of otters either by local people or parties, mainly at industrial fish ponds, lakes, and riversides within the same period of time. Forty-eight samples from six populations were recognized as Johor, Perak, Terengganu, Kelantan, Ranong, and Thale Noi in this study. Only the identified A. cinereus species samples are listed in Table 1. Figure 1 summarizes the sampling location of this study. All samples were obtained with the help of various parties such as the Department of Wildlife and National Parks (Peninsular Malaysia), zoos in Malaysia, the Museum of Zoology (Universiti Kebangsaan Malaysia, 
TABLE 1: List of samples.

\begin{tabular}{|c|c|c|c|c|}
\hline Species & Haplotype & Sample & Locality & State \\
\hline A. cinereus & Hap 7 & Sg_Sarang_Buaya_2 & Sg Sarang Buaya & Johor, Malaysia \\
\hline A. cinereus & Hap 7 & Sg_Pontian_Besar_2 & Sg Pontian besar & Johor, Malaysia \\
\hline A. cinereus & Hap 1 & Sg_Pontian_Besar_4 & Sg Pontian besar & Johor, Malaysia \\
\hline A. cinereus & Hap 1 & Parit_Karang_5 & Parit Karang & Johor, Malaysia \\
\hline A. cinereus & Hap 1 & Parit_Karang_6 & Parit Karang & Johor, Malaysia \\
\hline A. cinereus & Hap 4 & Kuala_Gula_71 & Kuala Gula & Perak, Malaysia \\
\hline A. cinereus & Hap 4 & Kuala_Gula_7 & Kuala Gula & Perak, Malaysia \\
\hline A. cinereus & Hap 4 & Kuala_Gula_8 & Kuala Gula & Perak, Malaysia \\
\hline A. cinereus & Hap 5 & Penarik_5 & Penarik & Terengganu, Malaysia \\
\hline A. cinereus & Hap 5 & Penarik_1 & Penarik & Terengganu, Malaysia \\
\hline A. cinereus & Hap 5 & Penarik_93 & Penarik & Terengganu, Malaysia \\
\hline A. cinereus & Hap 5 & Penarik_13 & Penarik & Terengganu, Malaysia \\
\hline A. cinereus & Hap 5 & Penarik_14 & Penarik & Terengganu, Malaysia \\
\hline A. cinereus & Hap 3 & Kg_Padang_Salim_71 & Kg Padang Salim & Kelantan, Malaysia \\
\hline A. cinereus & Hap 3 & Kg_Padang_Salim_72 & Kg Padang Salim & Kelantan, Malaysia \\
\hline A. cinereus & Hap 3 & Kg_Padang_Salim_8 & Kg Padang Salim & Kelantan, Malaysia \\
\hline A. cinereus & Hap 3 & Kg_Padang_Salim_11 & Kg Padang Salim & Kelantan, Malaysia \\
\hline A. cinereus & Hap 3 & Kg_Padang_Salim_10 & Kg Padang Salim & Kelantan, Malaysia \\
\hline A. cinereus & Hap 3 & Tumpat_304 & Tumpat & Kelantan, Malaysia \\
\hline A. cinereus & Hap 3 & Tumpat_303 & Tumpat & Kelantan, Malaysia \\
\hline A. cinereus & Hap 3 & Tumpat_12 & Tumpat & Kelantan, Malaysia \\
\hline A. cinereus & Hap 3 & Tumpat_14 & Tumpat & Kelantan, Malaysia \\
\hline A. cinereus & Hap 3 & Tumpat_15 & Tumpat & Kelantan, Malaysia \\
\hline A. cinereus & Hap 2 & Ranong_64 & Ranong & Thailand \\
\hline A. cinereus & Hap 2 & Ranong_5 & Ranong & Thailand \\
\hline A. cinereus & Hap 2 & Ranong_6 & Ranong & Thailand \\
\hline A. cinereus & Hap 2 & Ranong_7 & Ranong & Thailand \\
\hline A. cinereus & Hap 2 & Ranong_8 & Ranong & Thailand \\
\hline A. cinereus & Hap 6 & Thale_Noi_70 & Thale Noi & Thailand \\
\hline A. cinereus & Hap 6 & Thale_Noi_65 & Thale Noi & Thailand \\
\hline A. cinereus & Hap 6 & Thale_Noi_66 & Thale Noi & Thailand \\
\hline A. cinereus & Hap 6 & Thale_Noi_68 & Thale Noi & Thailand \\
\hline A. cinereus & Hap 6 & Thale_Noi_72 & Thale Noi & Thailand \\
\hline L. perspicillata & & L. perspicillata_2 & Alai & Melaka, Malaysia \\
\hline \multirow[t]{2}{*}{ L. perspicillata } & & L. perspicillata_5 & Alai & Melaka, Malaysia \\
\hline & & Eurasian & & GenBank \\
\hline
\end{tabular}

UKM), Phnom Tamao Zoological Park and Wildlife Rescue Center, and Wakayama Adventure World. Fecal samples were used in this study. All samples were preserved in a TRIS, EDTA, ethanol, and/or SDS solution to prevent damage. The samples were kept in a refrigerator at $-20^{\circ} \mathrm{C}$ or $-80^{\circ} \mathrm{C}$. Total genomic DNA was extracted by using the standard extraction kit and the protocol provided by the Qiagen DNeasy Stool Kit [44].

2.2. DNA Amplification. Polymerase chain reaction (PCR) was performed using a $25 \mu \mathrm{L}$ reaction mixture containing $1 \mu \mathrm{L}$ of genomic DNA, $2.5 \mu \mathrm{L}$ PCR Buffer 10X, $1 \mu \mathrm{L} 50 \mathrm{mM} \mathrm{MgCl}_{2}$, $0.5 \mu \mathrm{L} 10 \mathrm{mM}$ dNTP mix, $1.5 \mu \mathrm{L}$ each of $10 \mathrm{pmol} / \mu \mathrm{L}$ primer, and 4 units of Taq DNA Polymerase in PTC-100 Thermal Cycler (MJ Research Inc.). The partial D-loop fragment of approximately 450 base pairs was amplified using forward primer TANA-B ( $5^{\prime}$-CGA AGC TTG ATA TGA AAA ACC ATC GTT G-3 $3^{\prime}$ ) and reverse primer TANA-A ( $5^{\prime}$-GGA ATT CAT CTC TCC CGG TTT ACA AGA C-3') [45]. PCR conditions were as follows: 4 min denaturation at $94^{\circ} \mathrm{C}$, followed by 30 cycles of $30 \mathrm{sec}$ at $94^{\circ} \mathrm{C}, 30 \mathrm{sec}$ at $56^{\circ} \mathrm{C}, 1 \mathrm{~min}$ at $72^{\circ} \mathrm{C}$, and a final $7 \mathrm{~min}$ extension at $72^{\circ} \mathrm{C}$, before cooling to $4^{\circ} \mathrm{C}$ for $10 \mathrm{~min}$. DNA from PCR products was purified using the Vivantis G-F1 PCR Clean-up Kit and was sent directly to the sequencing service company, First Base Sdn. Bhd., to be sequenced.

2.3. Species Identification and Phylogenetic Analysis. Sequencing results were exported as FASTA sequence files. Sequences from GenBank were obtained as positive 


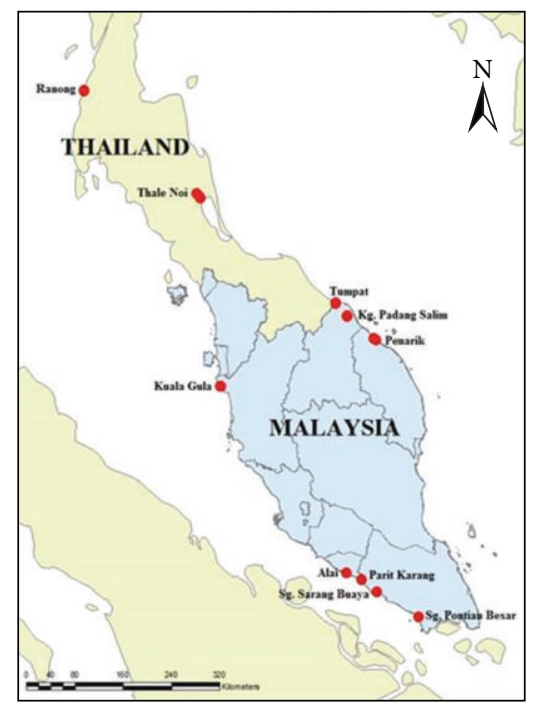

FIgURE 1: Sampling location of otter samples used in this study.

controls for each species before the species was identified. The D-loop sequences of the studied samples were aligned using the ClustalW multiple alignment algorithm of BioEdit, together with control sequences from GenBank and an outgroup sequence of the palm civet. Identification at the species level was detected by informative polymorphic sites assigned to each species. All sequences were analyzed using PAUP 4.0b10 and MrBayes 3.1 for phylogeny reconstruction. Two methods of analysis in PAUP included the following: (1) neighbor-joining (NJ) with Kimura 2 Parameter [46], which takes into account the unequal rates of evolution of transition and transversion but assumes an equal distribution of nucleotide composition and (2) Maximum Parsimony (MP) with stepwise addition (1000 replicates) in heuristic search [47] and 50\% majority rule consensus. In Maximum Parsimony (MP), gaps are treated as missing data, transitions and transversions are weighted equally, and heuristic search is performed with the TBR branch-swapping algorithm. All trees were subjected to bootstrap analysis with 1000 replicates to get bootstrap value support.

2.4. Genetic Structure of A. cinereus . Measures of population genetic parameters such as genetic diversity, nucleotide diversity, and nucleotide divergence among populations after nucleotide diversity was accounted for within populations $\left(D_{a}\right)$ were estimated from the mtDNA dataset using DNASP 4.0 [48]. The demographic history was examined with Tajima's test of neutrality, $D$ test [49], and Fu's statistics test [50], to test for deviation in sequence variation from evolutionary neutrality. The tests compare the number of singleton mutations to the total number $(D)$ and the average number of nucleotide differences between pairs of sequences $(F)$, both under a neutral model [51].

Population bottlenecks and expansions, selective sweeps on the mtDNA, and mutational rate heterogeneity may all result in a Poisson distribution of substitution differences

\begin{tabular}{lrrr}
\hline & & 1111222 & 222222 \\
& 1122223555 & 5563699223 & 447899 \\
& 3601271024 & 6958268890 & 268913 \\
\hline L.perspicillata TP7 & TTATTCCTCC & CTCGGCGCAT & CCCACG \\
L.perspicillata TP6 & TTATTCCTCC & CTCGGCGCAT & CCCACG \\
L.perspicillata TP5 & TTATTCCTCC & CTCGGCGCAT & CCCACG \\
A. cinereus TM 12 & CCCCTCTTCC & CTCGGGGTGC & CTCACA \\
A. cinereus TM 14 & CCCCTCTTCC CTCGGGGTGC & CTCACA \\
A. cinereus TM 15 & CCCCTCTTCC CTCGGGGTGC & CTCACA \\
L. sumatrana JHR & CCATCGCCAG AATCAGACAC & TCTGTA \\
L. sumatrana BR & CCATCGCCAG AATCAGACAC & TCTGTA \\
L. sumatrana KR & CCATCGCCAG AATCAGACAC & TCTGTA
\end{tabular}

Figure 2: Polymorphic sites for $L$. perspicillata, A. cinereus, and $L$. sumatrana used to identify the species.

between pairs of haplotypes [52]. Therefore, mismatch distribution analysis was performed using Arlequin version 3.0 with 1000 permutations [53] and site-frequency spectra [54] as implemented in DNASP 4.0.

The population genetic structure was analyzed for samples with five or more individuals, with an analogue of Fst, Ost, as implemented in an analysis of molecular variance AMOVA [55] in Arlequin 3.0. The statistical significance was tested using 1000 permutations. The parsimony criterion was used to reconstruct the haplotype relationships of $A$. cinereus, assuming that differences at any given site between two randomly drawn haplotypes were unlikely to have arisen from more than 1 mutational step [56]. A minimum-spanning network was generated using Network 4.5.0.2 [57] to illustrate this relationship.

\section{Results}

DNA from all 48 fecal samples was successfully extracted and sequenced. The partial D-loop sequences (398 bp) were converted into the FASTA format and were aligned with our control sequences of the three species L. perspicillata, A. cinereus, and L. sumatrana to identify species based on site polymorphisms. Based on the primers used in this study, several specific polymorphism sites were detected for each species including deletions and an insertion. Figure 2 shows the informative polymorphic sites for all three species used for species identification in this study. Thirty informative sites were observed from the $398 \mathrm{bp}$ sequence data set of the three species. Deletions and an insertion occurred specifically in the L. sumatrana species: deletions at site numbers $46-50$ (134-136 at the full length sequence sites) and an insertion at site number 134 (201 at the full length sequence site). Among the 48 samples, 33 were identified as A. cinereus, seven as L. sumatrana, and eight as L. perspicillata. They are listed in Table 1.

In the sequence analysis of the $33 \mathrm{~A}$. cinereus samples, out of $405 \mathrm{bp}$ partial sequences, 371 characters are conserved sites, and 34 characters are variable sites. Among the variable characters, 19 are singletons, and 15 characters are parsimony informative. The analysis showed that $8.4 \%$ of the total lengths are variable sites and about $3.7 \%$ are parsimony 
TABLE 2: Nucleotide diversity $P_{i}(\mathrm{t})$ and nucleotide divergence $\left(D_{a}\right)$ between populations.

\begin{tabular}{lcc}
\hline Populations & $\begin{array}{c}\text { Nucleotide } \\
\text { diversity } P_{i} \\
(\mathrm{t})\end{array}$ & $\begin{array}{c}\text { Nucleotide } \\
\text { divergence } \\
\left(D_{a}\right)\end{array}$ \\
\hline Johor-Ranong & 0.00593 & 0.00909 \\
Johor-Kelantan & 0.00493 & 0.00912 \\
Johor-Thale Noi & 0.00430 & 0.00616 \\
Johor-Terengganu & 0.00431 & 0.00618 \\
Johor-Perak & 0.00284 & 0.00324 \\
Ranong-Kelantan & 0.00264 & 0.00554 \\
Ranong-Thale Noi & 0.00138 & 0.00248 \\
Ranong-Terengganu & 0.00462 & 0.00462 \\
Ranong-Perak & 0.00462 & 0.00462 \\
Kelantan-Thale Noi & 0.00132 & 0.00132 \\
Kelantan-Terengganu & 0.00396 & 0.00831 \\
Kelantan-Perak & 0.00223 & 0.00223 \\
Thale Noi-Terengganu & 0.00308 & 0.00554 \\
Thale Noi-Perak & 0.00155 & 0.00290 \\
Terengganu-Perak & 0.00155 & 0.00290 \\
\hline
\end{tabular}

informative sites. The nucleotide compositions for the entire 405 bp sequences are as follows: $T=29.5 \%, C=30.6 \%$, $A=24 \%$, and $G=15.9 \%$.

Among the 33 individuals sequenced, 7 haplotypes were identified. Johor had two haplotypes (Hap 7 and Hap 1). Except for Johor, populations that represent each state have only a haplotype with no sharing haplotype detected. The haplotypes are as follows: Perak (Hap 4), Terengganu (Hap 5), Kelantan (Hap 3), Ranong Thailand (Hap 2), and Thale Noi (Hap 6).

The nucleotide diversity $P_{i}(\mathrm{t})$ among the populations was low, ranging from $0.1 \%$ to $0.6 \%$ (Table 2). The highest $P_{i}(\mathrm{t})$ value was between Johor and Ranong $(0.6 \%)$, while the lowest $P_{i}(\mathrm{t})$ value was between Kelantan and Thale Noi $(0.13 \%)$. The net nucleotide divergence $\left(D_{a}\right)$ among the populations was also low, ranging from $0.1 \%$ to $0.9 \%$. The highest $D_{a}$ value was between Johor and Kelantan populations (0.91\%), while the lowest $D_{a}$ value was between Kelantan and Thale Noi populations $(0.13 \%)$.

Phylogenetically, the NJ and MP trees shared the same tree topologies (Figures 3 and 4). From both trees, all otter species were grouped together distinct from the outgroup sample of the Eurasian otter (GenBank). In the main clade (clade A), the A. cinereus samples were grouped together in another clade (clade B) distinct from the outgroup samples of $L$. perspicillata (clade $C$ ). In the major clade of $A$. cinereus samples were two other clades (clade D and clade E) with $96 \%$ bootstrap support. CladeD consisted of samples from Kelantan (Kg Padang Salim and Tumpat) and Thailand (Ranong and Thale Noi). Samples from the two Kelantan populations formed a monophyletic clade distinct from the monophyletic clade of Ranong and Thale Noi. However, the clustering of each group was not supported by high bootstrap values $(<70 \%)$. In clade E, two subclades formed, also with low bootstrap values. The first subclade consisted of samples from Terengganu (Penarik), and the second subclade consisted of two monophyletic clades from Perak (Kuala Gula) and Johor (Sg Sarang Buaya and Pontian). The tree topologies showed two cluster patterns by population: the east coast Malaysian-southern Thai population (Kelantan, Thale Noi, and Ranong) and the southern, northern, and east coast Malaysian population (Perak, Johor, and Terengganu).

Due to the limited number of haplotypes in each population, a mismatch distribution analysis was not suitable in this study except for the population involving two countries, Thailand and Malaysia. Two populations were observed for mismatch analysis after the haplotypes of each state of each country were merged (Figure 6). The scatterplot of Malay Peninsula population indicated multimodal mismatch distribution from the observed frequencies of pairwise differences among the D-loop sequences and the expected frequencies under the sudden and spatial expansion models. However, Thai population indicated unimodal interpretation of mismatch distribution by following the sudden and spatial expansion models (Figure 6).

Genetic distance analysis was performed using the Kimura 2 Parameter (Table 3). Results showed that the $A$. cinereus samples are greatly distanced from $L$. perspicillata (>0.0309). Among the populations, the samples from Malay Peninsula states are closer to each other and highly distant from Thai population except for Kelantan. Kelantan population was closer to Thai population (0.0044) than to the other Malay Peninsula states (0.0079-0.0100).

Differentiation between individual haplotypes within groups was low, with most separated by single base substitutions. The minimum-spanning network that describes the relationships between the population haplotypes is shown in Figure 5. Two distinct networks were observed between haplogroup A (Hap 2, Hap 3, and Hap 6) and haplogroup B (Hap 1, Hap 4, Hap 5, and Hap 7).

\section{Discussion}

DNA from all fecal samples was extracted, amplified, and sequenced successfully. Thirty-three of 48 samples were identified as $A$. cinereus through site polymorphisms. The primer used in this study was useful for mini-DNA barcoding for the three Malaysian otter species. The use of a fresh noninvasive sample source, feces, with the D-loop primer pairs would be suitable for forensic analysis in the future especially for identifying species. As many as 30 informative sites were observed for species-specific differentiation among the three species $L$. perspicillata, A. cinereus, and L. sumatrana, which represented $7.5 \%$ of the total sequence length including some deletions and an insertion in the $L$. sumatrana sequences. The deletion and insertion events in $L$. sumatrana provided the initial idea that $L$. sumatrana differs from the other two species based on the observed DNA barcodes, thus supporting findings by Koepfli et al. [14]. Our finding also contradicts the previous phylogeny classification based on the morphological characteristics of the grouping of L. sumatrana and L. perspicillata in one group 
TABLE 3: Genetic distance analysis among populations for A. cinereus D-loop sequences.

\begin{tabular}{lcccc}
\hline & Johor & Perak & Terengganu & Kelantan \\
\hline Johor & & & & \\
Perak & 0.0041 & & & \\
Terengganu & 0.0071 & 0.0029 & 0.0088 & 0.0044 \\
Kelantan & 0.0100 & 0.0079 & 0.0094 & 0.0324 \\
Thailand & 0.0085 & 0.0069 & 0.0353 & 0.0309 \\
L. perspicillata & 0.0353 & 0.0324 & & \\
\hline
\end{tabular}

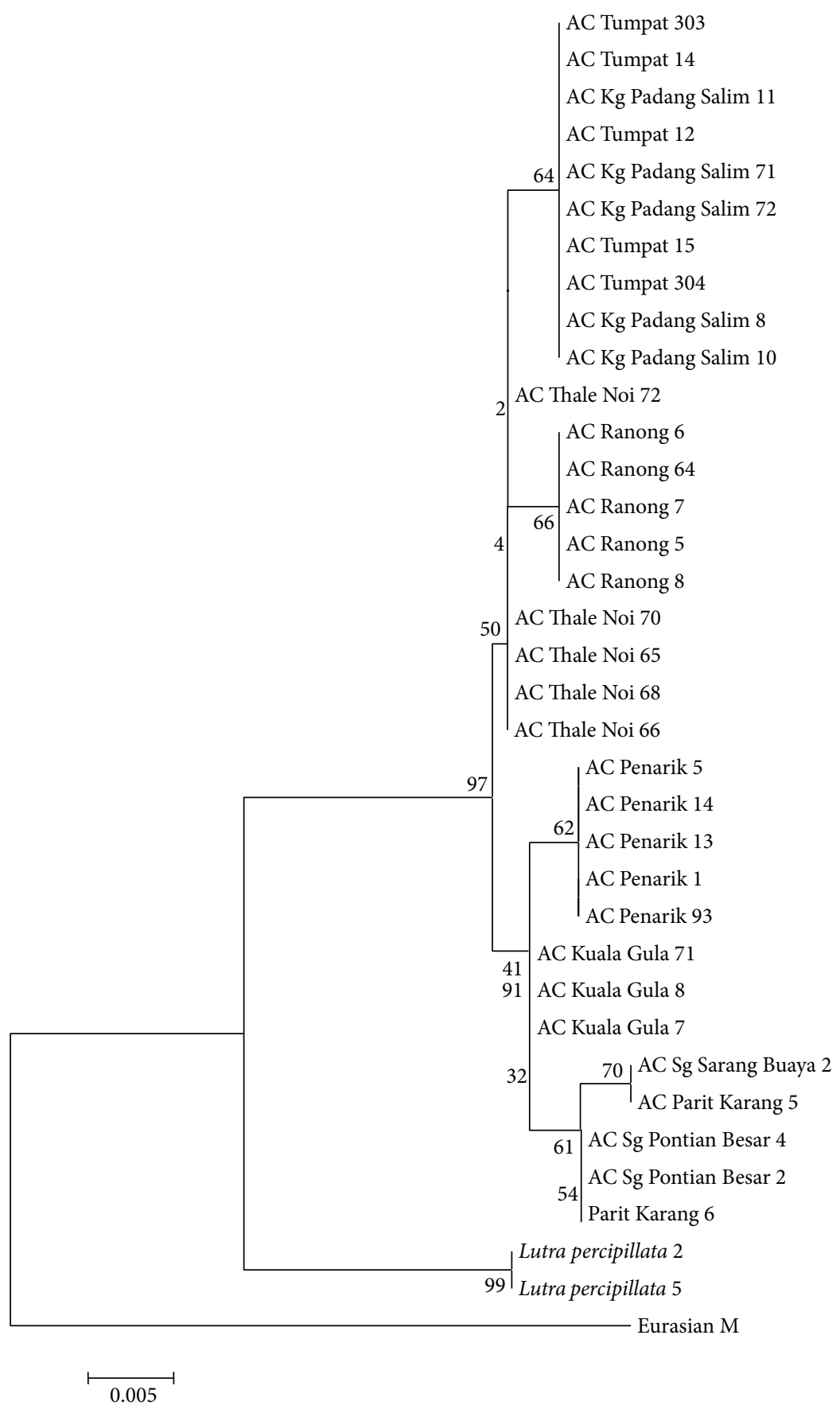

FIGURE 3: NJ tree topology for studied samples. The number at the branches indicates the bootstrap values for 1000 replications. 


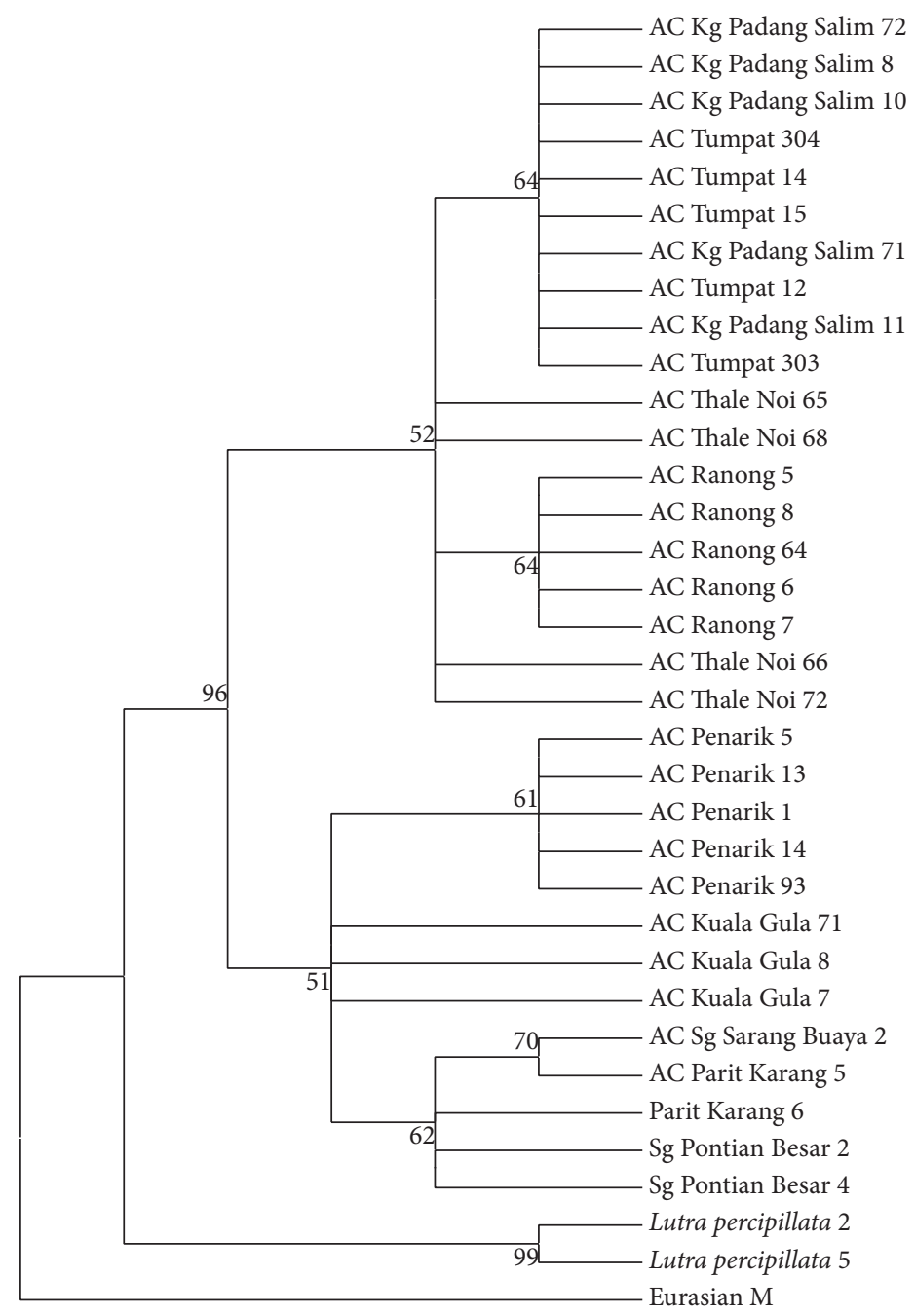

FIgURE 4: MP tree topology for studied samples. The number at the branches indicated the bootstrap values of 1000 replications.

distinct from A. cinereus [19-21]. However, L. perspicillata ta and $A$. cinereus have significant differences in morphological characteristics and ecological aspects such as body mass and diet selection [58]. According to Koepfli et al. [14], based on continuous observation, there are some possible explanations for this grouping. (a) Hybridization between the two species may occur and is not impossible since the two species have the same chromosome number, $2 n=38$. (b) The species share a similar brain structure with a bigger rear sigmoid gyrus that gives higher tactile sensitivity, influencing similarities in foraging activity for both species. (c) Based on extinct Lutrogale paleoleptonyx and Lutrogale robusta fossils found in Java, Indonesia, both Lutrogale species have teeth structures suitable for eating shelled foods, a diet similar tothat of $A$. cinereus. In short, the DNA barcode of the three species can be used for species identification studies.

Haplotype analysis showed that there are seven haplotypes, and only Johor state has two haplotypes. The analysis showed that the $A$. cinereus samples from each population are highly endemic based on the partial D-loop sequences. This was supported by the low nucleotide diversity among populations valued below $0.6 \%$. The nucleotide divergence $D_{a}$ was also observed to be low among populations with the highest $D_{a}$, between Johor and Ranong (0.91\%), which was proportional to the largest distance among other states.

Phylogenetically, all $A$. cinereus samples were excluded from the outgroups, the Eurasian otter and L. perspicillata. In the major $A$. cinereus clade, two subclades formed. The first subclade grouped all Malay Peninsula samples except for the samples from Kelantan. The second subclade grouped Kelantan samples with Thai samples. Kelantan samples were outliers in this study as Kelantan was only peninsular state grouped with Thai samples. Based on distance observation, Terengganu is closer to Kelantan, without any major natural barrier preventing gene flow between the two states. Both states are located on the east coast of Malaysia and are farther away from the other states examined in this study. However, genetic distance analysis supported the close relationships 


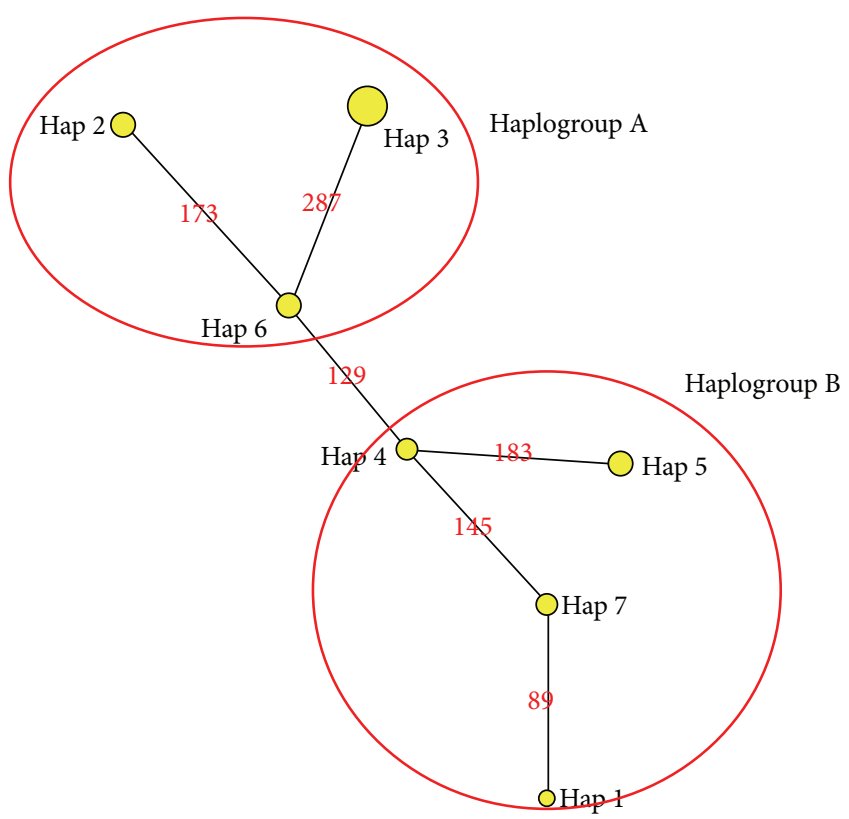

FIgURE 5: Minimum-spanning network of haplogroup A and haplogroup B.

of Thai and Kelantan samples compared to the samples from Terengganu and other Malaysian states. Our minimumspanning network also showed that the samples from Kelantan were grouped as a network with Thai populations. The other Malay Peninsula populations formed another group.

Based on the mismatch analysis for Malay Peninsula states, the observed pattern showed a disrupted flow chart and differed from the simulated pattern. However, the same analysis conducted for Thai populations showed that the observed pattern followed the simulated pattern significantly. These patterns suggested that a disruption exists among the population of Malay Peninsula, which is supported by the outlier formation of Kelantan samples in this study. No previous population study stated any close relationship within Malay Peninsular samples and with Thai populations in A. cinereus.

According to Lariviere [22], A. cinereus inhabits Bangladesh, Bhutan, Borneo, Brunei, southern China, southern India, Indonesia, Java, Karimun Island, Laos, Malay Peninsula, Myanmar, Palawan, Philippines, Sumatra, Thailand, and Vietnam. This species is likely extinct in Hong Kong and Singapore [28, 29]. Based on previous studies, several subspecies of $A$. cinereus have been recognized. Corbet and Hill [59] described three subspecies of $A$. cinereus in their book The Mammals of the Indo-Malayan Region: A Systematic Review. The three subspecies are A. c. fulvus (distributed in Vietnam), A. c. wurmbi (distributed in East Java), and A. c. nirnai (distributed in India). Lariviere [22] also described another two subspecies based on Harris's [60] recognition, A. c. cinereus and A. c. concolor (location not mentioned).
To date, there is no record of a Malay Peninsula subspecies. However, there is a subspecies named for the neighboring country, Thailand. According to Lekagul and McNeely [61], the subspecies of $A$. cinereus otter in Thailand is $A$. c. cinerea, recognized by Illiger (1815). Since this species is distributed mainly in Southeast Asia, A. c. cinerea could be distributed on Thai mainland and then migrated beyond the country's border to the adjacent Malaysian states Kelantan, Kedah, and Perlis. The phylogenetic trees and mismatch distribution analysis in this study supported this crosscountry migration. Results also showed that Kelantan-Thai subspecies is completely genetically distinct from $A$. cinereus of the other states of Malay Peninsula.

For further confirmation, another mismatch analysis was performed by excluding Kelantan population from Malay Peninsula (group 1) and combining it with the populations from Thailand (group 2). Results showed that the observed mismatch distribution pattern for both groups followed the simulated suggested patterns (Figure 6). These patterns suggested that the otters sampled from Kelantan are closer or most likely belong to Thai population and are quite different from the samples from other states. This finding shows that Thai subspecies A. c. cinerea may have migrated to Kelantan from Thai mainland. Genetically, these results also suggested the endemic exclusion of Malay Peninsula populations and distinction from Kelantan-Thai populations.

In this study, based on several population analyses, we suggest that Malay Peninsula small-clawed otter is different from Thai subspecies $A$. cinereus cinerea. We also suggest the classification of the new subspecies of Malay Peninsula small-clawed otter named $A$. cinereus kecilensis. This new subspecies might range from the southern to the northern part of Malay Peninsula. However, there was no confirmation that Thai subspecies occurs in the two states located next to Thailand, Perlis and Kedah.

In conclusion, fecal samples were a source for identifying species, which thus supports noninvasive sampling for genetic analysis. The primer pair used in this study was also significant for DNA barcoding for the three Malaysian species L. perspicillata, L. sumatrana, and A. cinereus. This study suggested new classification of Malay Peninsula small-clawed otter, A. cinereus kecilensis. However, additional samples from other states of Malay Peninsula are needed to confirm the range of Thai subspecies in Malaysia and the range of $A$. cinereus kecilensis in the northern states.

\section{Conflict of Interests}

The authors declare that there is no conflict of interests regarding the publication of this paper.

\section{Acknowledgments}

The authors are deeply indebted to several institutions that provided them with the necessary facilities and assistance for tissue sample collection, including the Faculty of Science and Technology, Universiti Kebangsaan Malaysia, the Department of Wildlife and National Parks (Malaysia), 


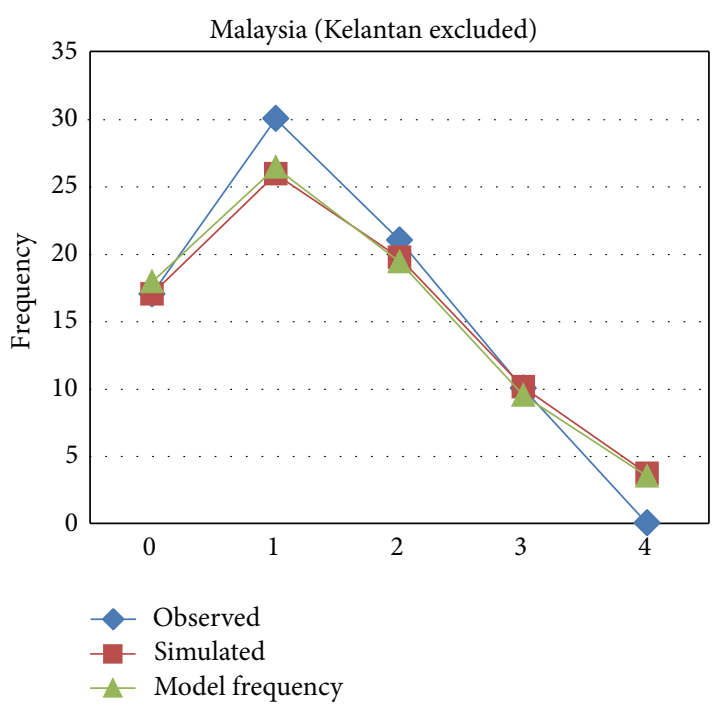

(a)

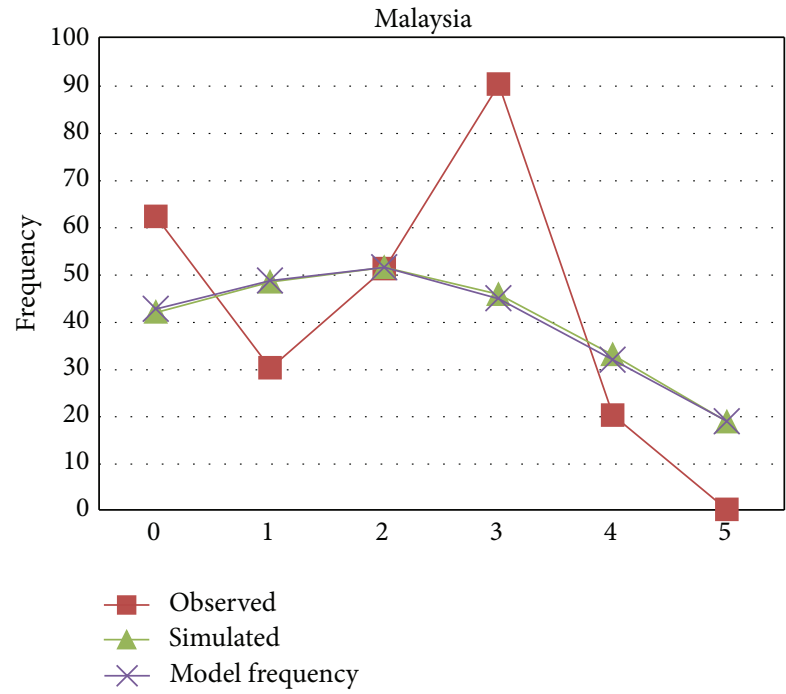

(c)

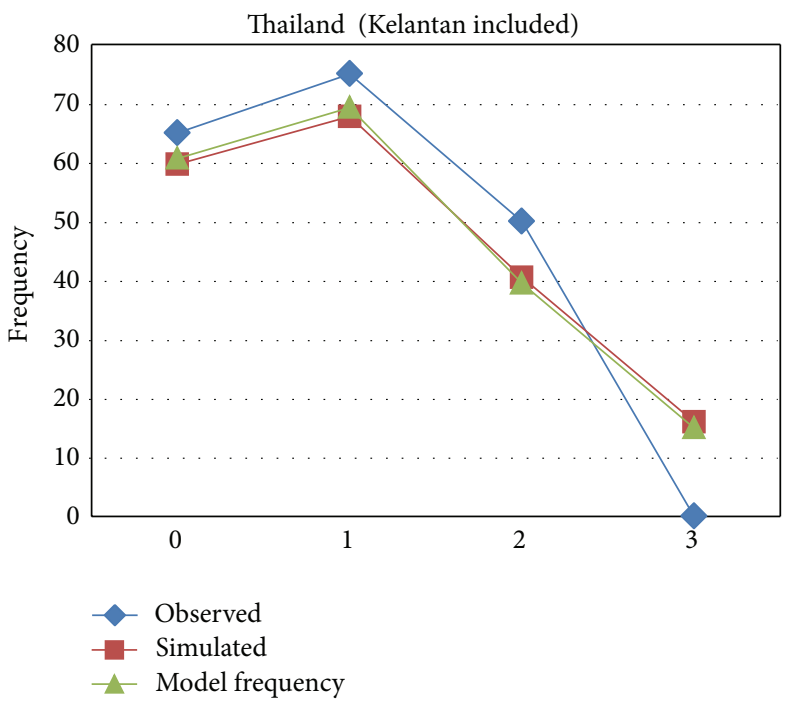

(b)

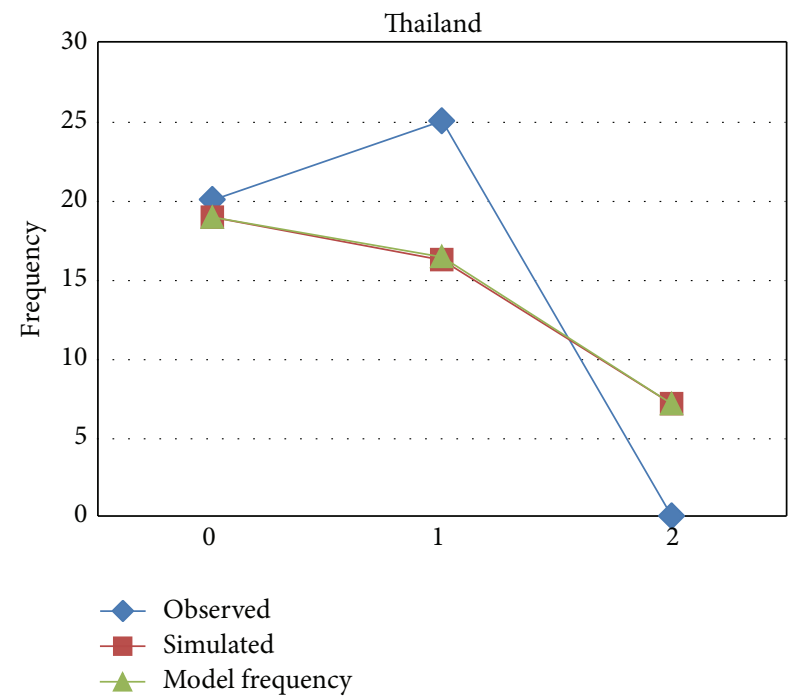

(d)

FIGURE 6: Mismatch distribution of the observed frequencies of pairwise differences among D-loop sequences and expected frequencies under the sudden and spatial expansion models, including and excluding Kelantan population for each country.

the Department of National Park, Wildlife and Plant Conservation (Thailand), zoos in Malaysia, the Museum of Zoology, Chikushi Jogakuen University Junior College, Phnom Tamao Zoological Park and Wildlife Rescue Center, and Wakayama Adventure World and Conservation International, Cambodia. The authors would also like to thank members of the Cytogenetic Laboratory, Faculty of Science and Technology, and Ms. Kittya Singthong. This research was made possible under Grants UKM-GUP-2011-183 and DLP-2013-006. This survey was partly supported by Chikushi Jogakuen Special Research Grant. Research in Thailand was conducted on the conservation measures of swamp forest through sustainable use of ecological resources by community forestry (E-092) supported by The Environment Research and Technology Development Fund.

\section{References}

[1] C. Bellis, K. J. Ashton, L. Freney, B. Blair, and L. R. Griffiths, "A molecular genetic approach for forensic animal species identification," Forensic Science International, vol. 134, no. 2-3, pp. 99-108, 2003.

[2] J. A. Darling and M. J. Blum, "DNA-based methods for monitoring invasive species: a review and prospectus," Biological Invasions, vol. 9, no. 7, pp. 751-765, 2007.

[3] J. D. Wells and J. R. Stevens, "Application of DNA-based methods in forensic entomology," Annual Review of Entomology, vol. 53, pp. 103-120, 2008.

[4] M. K. A. Rosli, S. S. Zakaria, S. M. F. Syed-Shabthar et al., "Phylogenetic relationships of Malayan gaur with other species of the genus Bos based on cytochrome $b$ gene DNA sequences," Genetics and Molecular Research, vol. 10, no. 1, pp. 482-493, 2011. 
[5] F. Pereira, J. Carneiro, A. Amorim, and F. Pereira, "Identification of species with DNA-based technology: current progress and challenges," Recent Patents on DNA \& Gene Sequences, vol. 2, no. 3, pp. 187-200, 2008.

[6] A. M. Nsubuga, M. M. Robbins, A. D. Roeder, P. A. Morin, C. Boesch, and L. Vigilant, "Factors affecting the amount of genomic DNA extracted from ape faeces and the identification of an improved sample storage method," Molecular Ecology, vol. 13, no. 7, pp. 2089-2094, 2004.

[7] N. L. Rogers, S. A. Cole, H.-C. Lan, A. Crossa, and E. W. Demerath, "New saliva DNA collection method compared to buccal cell collection techniques for epidemiological studies," American Journal of Human Biology, vol. 19, no. 3, pp. 319-326, 2007.

[8] Z. Yu and M. Morrison, "Improved extraction of PCR-quality community DNA from digesta and fecal samples," BioTechniques, vol. 36, no. 5, pp. 808-812, 2004.

[9] A. Ang, A. Srivasthan, B. M. Md-Zain, M. R. B. Ismail, and R. Meier, "Low genetic variability in the recovering urban banded leaf monkey population of Singapore," The Raffles Bulletin of Zoology, vol. 60, no. 2, pp. 589-594, 2012.

[10] S. M. F. Syed-Shabthar, M. K. A. Rosli, N. A. A. Mohd-Zin et al., "The molecular phylogenetic signature of Bali cattle revealed by maternal and paternal markers," Molecular Biology Reports, vol. 40, no. 8, pp. 5165-5176, 2013.

[11] S. A. Hussain, S. K. Gupta, and D. P. K. Silva, "Biology and ecology of Asian small-clawed otter Aonyx cinereus (Illiger, 1815): a review," IUCN Otter Specialist Group Bulletin, vol. 28, no. 2, pp. 63-75, 2011.

[12] K.-P. Koepfli and R. K. Wayne, "Phylogenetic relationships of otters (Carnivora: Mustelidae) based on mitochondrial cytochrome $b$ sequences," Journal of Zoology, vol. 246, no. 4, pp. 401-416, 1998.

[13] D. E. Wilson and D. M. Reeder, Mammal Species of the World: A Taxonomic and Geographic Reference, Smithsonian Institute Press, Washington, DC, USA, 2nd edition, 1993.

[14] K.-P. Koepfli, B. Kanchanasaka, H. Sasaki et al., "Establishing the foundation for an applied molecular taxonomy of otters in Southeast Asia," Conservation Genetics, vol. 9, no. 6, pp. 15891604, 2008.

[15] K.-P. Koepfli, K. A. Deere, G. J. Slater et al., "Multigene phylogeny of the Mustelidae: resolving relationships, tempo and biogeographic history of a mammalian adaptive radiation," BMC Biology, vol. 6, article 10, 2008.

[16] S. M. Shariff, "Some observations on otters at Kuala Gula, Perak and National Park, Pahang," Journal of Wildlife and Parks, vol. 3, pp. 75-88, 1984.

[17] H. M. N. Burhanuddin and N. Ahmad, "A survey on the distribution of otters in Pulau Pinang and Perlis," Journal of Wildlife and Parks, vol. 9, pp. 53-58, 1990.

[18] N. Sivasothi and H. M. N. Burhanuddin, "A review of otters (Carnivora: Mustelidae: Lutrinae) in Malaysia and Singapore," Hydrobiologia, vol. 285, no. 1-3, pp. 151-170, 1994.

[19] C. G. van Zyll de Jong, "A phylogenetic study of the Lutrinae (Carnivora; Mustelidae) using morphological data," Canadian Journal of Zoology, vol. 65, no. 10, pp. 2536-2544, 1987.

[20] C. G. van Zyll de Jong, "A brief review of the systematics and a classification of the Lutrinae," Habitat, vol. 6, pp. 79-83, 1991.

[21] G. F. Willemsen, A Revision of the Pliocene and Quaternary Lutrinae from Europe, vol. 101 of Scripta Geologica, Nationaal Natuurhistorisch Museum, Leiden, The Netherlands, 1992.
[22] S. Lariviere, “Amblonyx cinereus," Mammalian Species, vol. 720, pp. 1-5, 2003.

[23] International Union for Conservation of Nature of Otter Specialist Group (IUCN OSG), 2012, http://www.otterspecialistgroup.org/Species/Lutra_sumatrana.html.

[24] C. G. van Zyll de Jong, A Systematic Review of the Nearctic and Neotropical River Otters (Genus Lutra, Mustelidae Carnivora), vol. 80 of Life Sciences Contributions, Royal Ontario Museum, Toronto, Canada, 1972.

[25] J. Ruiz-Olmo and S. Palazón, "The diet of the European otter (Lutra lutra L., 1758) in Mediterranean freshwater habitats," Journal of Wildlife Research, vol. 2, no. 2, pp. 171-181, 1997.

[26] S. A. Hussain, "Status of otter conservation in India," ENVIS Bulletin Wildlife and Protected Areas, vol. 2, no. 2, pp. 92-97, 1999.

[27] M. Hoffmann, C. Hilton-Taylor, A. Angulo et al., "The impact of conservation on the status of the world's vertebrates," Science, vol. 330, no. 6010, pp. 1503-1509, 2010.

[28] P. Foster-Turley and C. Santiapillai, "Action plan for Asian otters," in Otters: An Action Plan for Their Conservation, P. Foster-Turley, S. Macdonald, and C. Mason, Eds., pp. 52-63, IUCN/SSC Otter Specialist Group, Geneva, Switzerland, 1990.

[29] A. Sebastian, "The hairy-nosed otter in Peninsular Malaysia," IUCN Otter Specialist Group Bulletin, vol. 11, article 3, pp. 1-57, 1995.

[30] R. Melisch, P. B. Asmoro, and L. Kusumawardhani, "Major steps taken towards otter conservation in Indonesia," IUCN Otter Specialist Group Bulletin, vol. 10, pp. 21-24, 1994.

[31] H. M. N. Burhanuddin, "Preliminary study on food preference of Lutra perspicillata and Aonyx cinerea in Tanjung Piandang, Perak," Journal of Wildlife and Parks, vol. 8, pp. 47-51, 1989.

[32] P. A. Foster-Turley, "Conservation aspects of the ecology of Asian small-clawed and smooth otters on the Malay Peninsula," IUCN Otter Specialist Group Bulletin, vol. 7, pp. 26-29, 1992.

[33] H. Kruuk, B. Kanchanasaka, S. O’Sullivan, and S. Wanghongsa, "Niche separation in three sympatric otters Lutra perspicillata, L. lutra and Aonyx cinerea in Huai Kha Khaeng, Thailand," Biological Conservation, vol. 69, no. 1, pp. 115-120, 1994.

[34] H. M. N. Burhanuddin and N. Ahmad, "A survey on the distribution of otters in Pulau Pinang and Perlis," Journal of Wildlife and Parks, vol. 9, pp. 53-38, 1990.

[35] S. A. Hussain, "Conservation status of otters in the Tarai aand lower Himalayas of Uttar Pradesh, India," in Proceedings of the 7th International Otter Colloquium, pp. 131-142, Trebon, Czech Republic, 1998.

[36] K. C. Ang, J. W. H. Leow, W. K. Yeap, S. Hood, M. C. Mahani, and B. M. Md-Zain, "Phylogenetic relationships of the orang asli and iban of malaysia based on maternal markers," Genetics and Molecular Research, vol. 10, no. 2, pp. 640-649, 2011.

[37] B. M. Md-Zain, S. J. Lee, M. Lakim, A. Ampeng, and M. C. Mahani, "Phylogenetic position of Tarsius bancanus based on partial cytochrome $b$ DNA sequences," Journal of Biological Sciences, vol. 10, no. 4, pp. 348-354, 2010.

[38] B. M. Md-Zain, M. Mohamad, M. A. Ernie-Muneerah et al., "Phylogenetic relationships of Malaysian monkeys, Cercopithecidae, based on mitochondrial cytochrome c sequences," Genetics and Molecular Research, vol. 9, no. 4, pp. 1987-1996, 2010.

[39] L. S. Lim, K. C. Ang, M. C. Mahani, A. W. Shahrom, and B. M. Md-Zain, "Mitochondrial DNA polymorphism and phylogenetic relationships of proto Malays in Peninsular Malaysia," Journal of Biological Sciences, vol. 10, no. 2, pp. 71-83, 2010. 
[40] W. A. Khan, M. Qasim, E. Ahmad, and H. B. Bhaagat, "Distribution of smooth coated otter (Lutrogale perspicillata) in Sindh, Pakistan," Tech. Rep. WWF-P, Islamabad and Sindh Wildlife Department, Sindh, Pakistan, 2008.

[41] X. Cai, X. Gou, L. Jiang, and T. Mipam, "Bioinformatic analysis of phylogenetic evolution of Chinese cattle," in Proceedings of the 5th International Conference on Bioinformatics and Biomedical Engineering (iCBBE '11), pp. 1-3, Wuhan, China, May 2011.

[42] S. Jia, Y. Zhou, C. Lei et al., "A new insight into cattle's maternal origin in six Asian countries," Journal of Genetics and Genomics, vol. 37, no. 3, pp. 173-180, 2010.

[43] P. Q. Ya, Z.-T. Chu, Q. Dai et al., "Mitochondrial DNA polymorphisms in Yunnan nationalities in China," Journal of Human Genetics, vol. 46, no. 4, pp. 211-220, 2001.

[44] P. Simonelli, C. Troedsson, J. C. Nejstgaard, K. Zech, J. B. Larsen, and M. E. Frischer, "Evaluation of DNA extraction and handling procedures for PCR-based copepod feeding studies," Journal of Plankton Research, vol. 31, no. 12, pp. 1465-1474, 2009.

[45] T. Sekiguchi, H. Sasaki, Y. Kurihara et al., "New methods for species and sex determination in three sympatric Mustelids, Mustela itatsi, Mustela sibirica and Martes melampus," Molecular Ecology Resources, vol. 10, no. 6, pp. 1089-1091, 2010.

[46] J. Pevsner, Bioinformatics and Functional Genomics, WileyBlackwell, Hoboken, NJ, USA, 2nd edition, 2009.

[47] D. L. Swofford, Phylogenetic Analysis Using Parsimony and Other Methods Version 4.0 Beta Version, Sinauer Associates, Sunderland, Mass, USA, 2002.

[48] J. Rozas, J. C. Sanchez-DelBarrio, X. Messeguer, and R. Rozas, "DnaSP, DNA polymorphism analyses by the coalescent and other methods," Bioinformatics, vol. 19, no. 18, pp. 2496-2497, 2003.

[49] F. Tajima, "Statistical method for testing the neutral mutation hypothesis by DNA polymorphism," Genetics, vol. 123, no. 3, pp. 585-595, 1989.

[50] Y.-X. Fu, "Statistical tests of neutrality of mutations against population growth, hitchhiking and background selection," Genetics, vol. 147, no. 2, pp. 915-925, 1997.

[51] Y.-X. Fu and W.-H. Li, "Statistical tests of neutrality of mutations," Genetics, vol. 133, no. 3, pp. 693-709, 1993.

[52] M. Slatkin and R. R. Hudson, "Pairwise comparisons of mitochondrial DNA sequences in stable \& exponentially growing populations," Genetics, vol. 129, no. 2, pp. 555-562, 1991.

[53] L. Excoffier, G. Laval, and S. Schneider, "Arlequin (version 3.0): an integrated software package for population genetics data analysis," Evolutionary Bioinformatics Online, vol. 1, pp. 47-50, 2005.

[54] M. J. Donnelly, M. C. Licht, and T. Lehmann, "Evidence for recent population expansion in the evolutionary history of the malaria vectors Anopheles arabiensis and Anopheles gambiae," Molecular Biology and Evolution, vol. 18, no. 7, pp. 1352-1364, 2001.

[55] S. Schneider, D. Roessli, and L. Excoffier, ARLEQUIN, Version 2.000: A Software for Population Genetics Data Analysis, Genetics and Biometry Laboratory, University of Geneva, Geneva, Switzerland, 2000.

[56] J. Alexandrino, J. W. Arntzen, and N. Ferrand, "Nested clade analysis and the genetic evidence for population expansion in the phylogeography of the golden-striped salamander, Chioglossa lusitanica (Amphibia: Urodela)," Heredity, vol. 88, no. 1, pp. 66-74, 2002.
[57] H.-J. Bandelt, P. Forster, and A. Rohl, "Median-joining networks for inferring intraspecific phylogenies," Molecular Biology and Evolution, vol. 16, no. 1, pp. 37-48, 1999.

[58] Y. T. Hwang and S. Lariviere, "Lutrogale perspicillata," Mammalian Species, vol. 786, pp. 1-4, 2005.

[59] G. B. Corbet and J. E. Hill, The Mammals of the Indomalayan Region: A Systematic Review, Oxford University Press, New York, NY, USA, 1992.

[60] C. J. Harris, Otters: A Study of the Recent Lutrinae, Weidenfeld \& Nicolson, London, UK, 1968.

[61] B. Lekagul and J. McNeely, Mammals of Thailand, Kurusaphra Laprao Press, Bangkok, Thailand, 1977. 

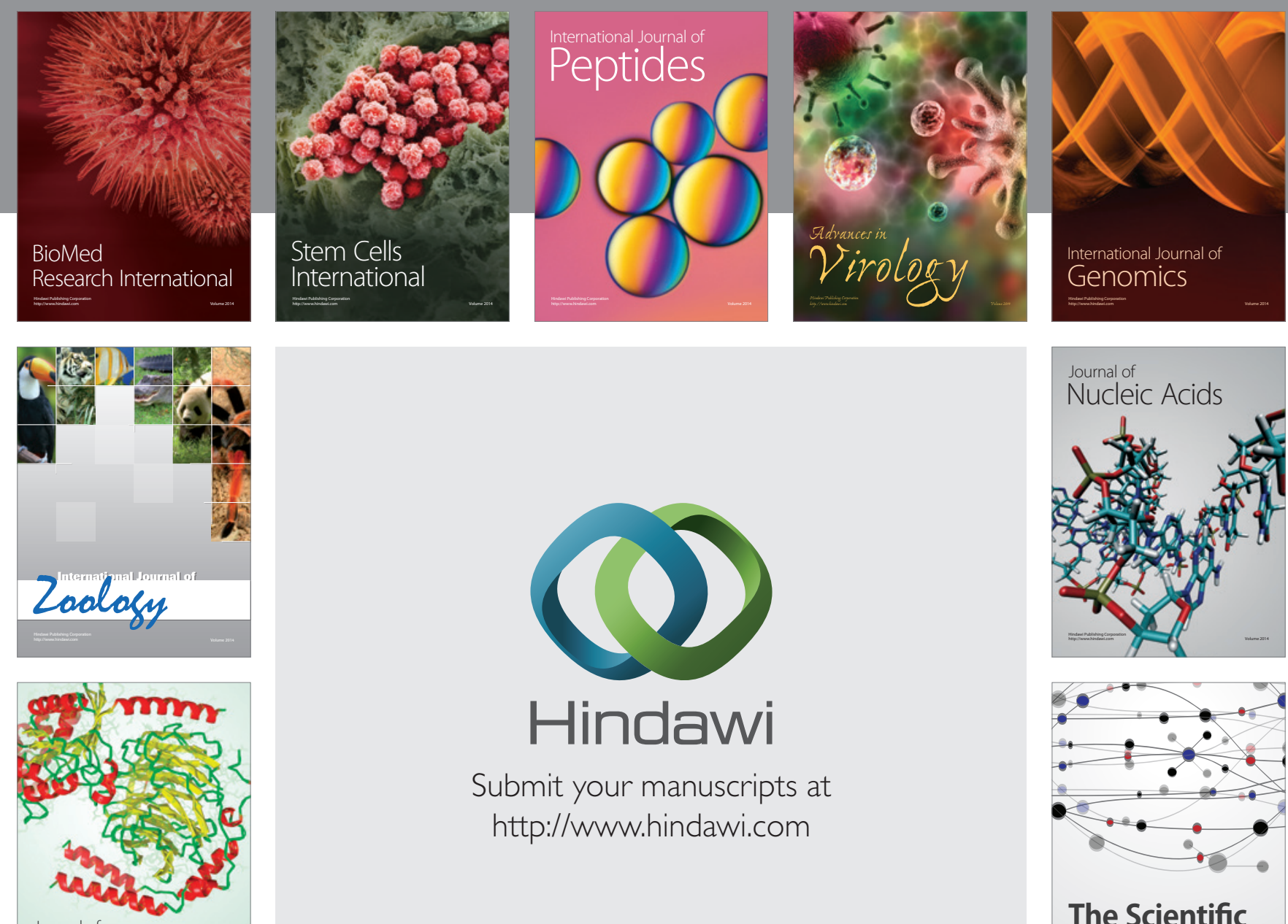

Submit your manuscripts at

http://www.hindawi.com

Journal of
Signal Transduction
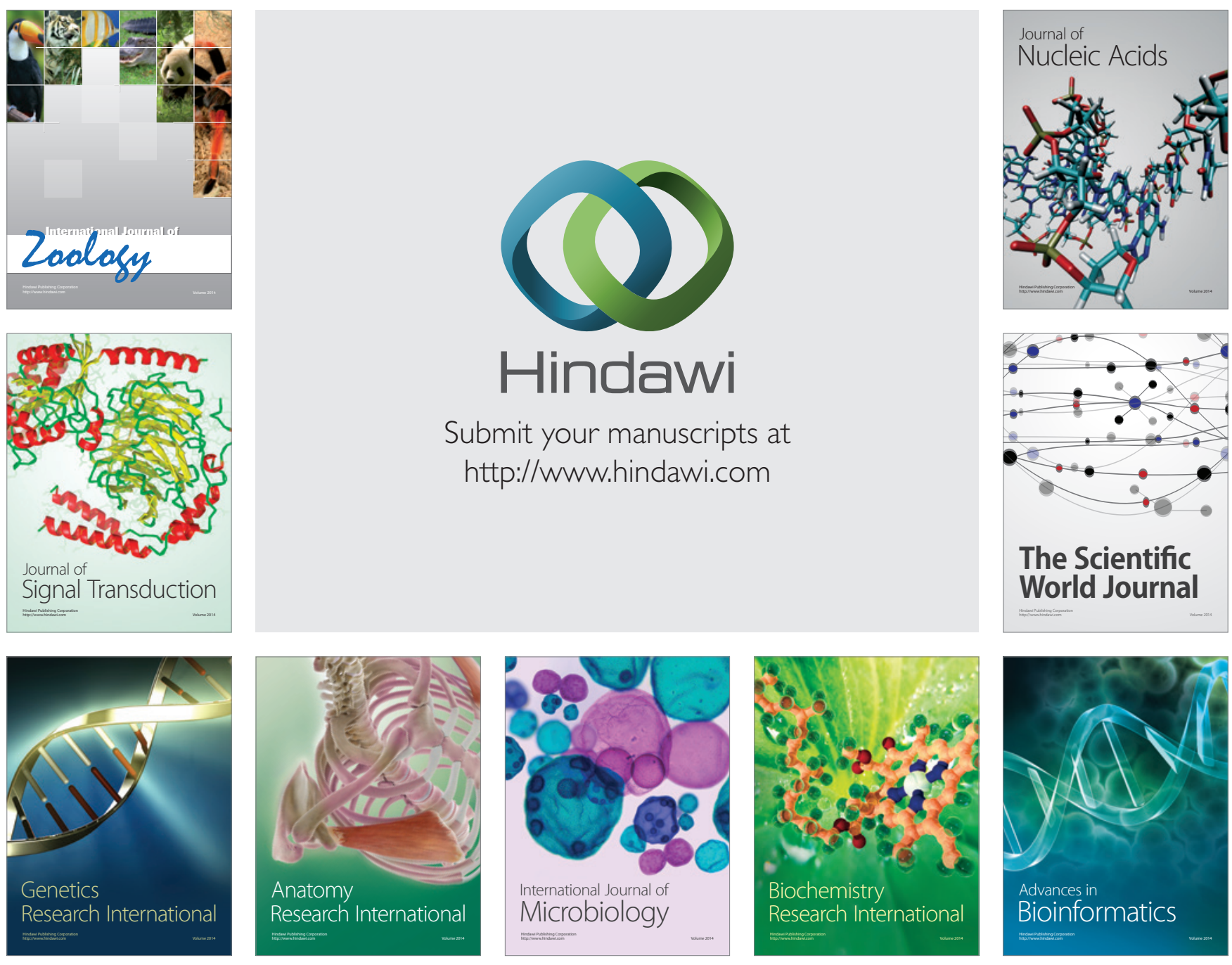

The Scientific World Journal
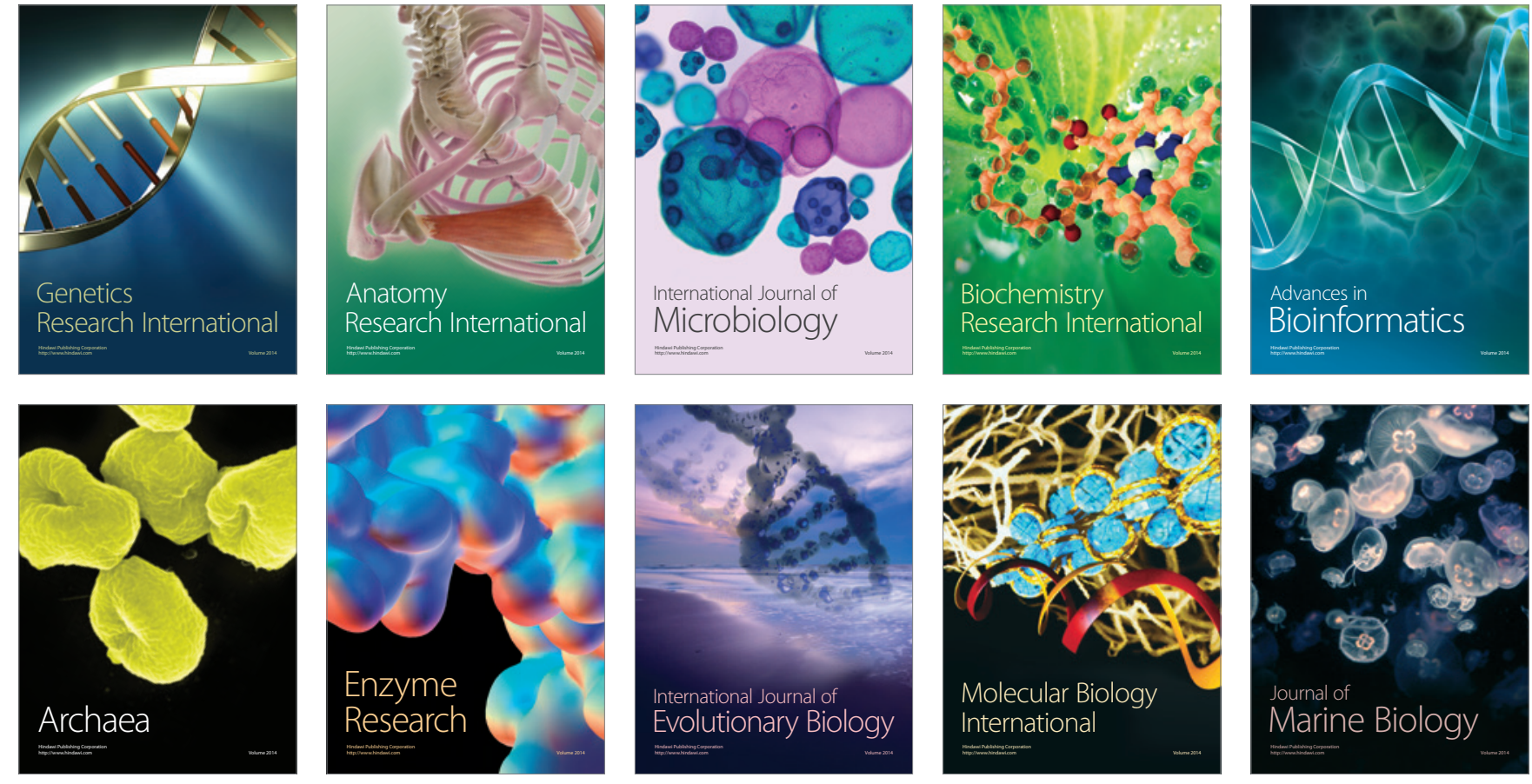